\title{
WOJNA UKRAIŃSKO-POLSKO-ROSYJSKA 1920 ROKU W INTERPRETACJI JEJ UCZESTNIKÓW ORAZ POLSKI KIERUNEK PROPAGANDY BOLSZEWICKIEJ (NA PRZYKLADZIE BOLSZEWICKICH ULOTEK KWIETNIA - WRZEŚNIA 1920)
}

\author{
Nadtoka O. M., \\ Doktor, Profesor nadzwyczajny starożytnej i nowożytnej historii Ukrainy, \\ Kijowski Uniwersytet Narodowy im. Tarasa Szewczenki, Wydziat Historyczny, Kijów, Ukraina \\ DOI: https://doi.org/10.31435/rsglobal_conf/25112020/7248
}

\begin{abstract}
In this publication the author analyzes the interpretations of the events of the UkrainianPolish-Russian war in 1920 by its participants. The Polish direction of Russian-Bolshevik propaganda in this war is also being explored. Sources of the study - a collection of Ukrainian agitation editions and Russian-Bolshevik leaflets published in Polish. These editions are stored in the Vernadsky National Library's Department of Old Books (Viddil starodrukiv Nacionalnoji biblioteky imeni $V$. Vernads'koho). The Bolshevik propaganda involved the creation of a new social consciousness in which the world of good and evil changed places, and the policy of Russian-Bolshevik expansion was presented as the liberation of peoples. The propaganda methods used by Soviet Russia involved the manipulation of consciousness not only through the traditional means of misinformation, inciting controversy, destroying the enemy's reputation, but also special techniques, which are defined as the methods of the overturned pyramid, absolute clarity, and the formation of controlled cognitive choice. Keywords: Ukrainian-Polish-Russian war, UNR Army, Polish Commonwealth Army, Red Army, Russian-Bolshevik propaganda, propaganda methods, manipulation of consciousness.
\end{abstract}

Wprowadzenie. Problemy wojny odrodzonej Ukrainy i Polski z Rosją Sowiecką, która od grudnia 1917 r. toczyła wojnę przeciwko Ukrainie, były szeroko badane w ciągu ostatnich dwóch dekad. W ukraińskiej historiografii wojna ta ma nazwę określoną przez schemat jej uczestników oraz specyfikę ówczesnej władzy politycznej w Rosji, konkretnie - wojna ukraińsko-polsko-sowiecką lub ukraińskopolsko-bolszewicką. W polskiej historiografii widzimy także pewną zmienność, ale zazwyczaj bez uwzględnienia w nazwie ukraińskiego elementu konfrontacji z rosyjskimi bolszewikami - wojna polskorosyjska lub polsko-bolszewicka. W proponowanej publikacji używamy nazwy wojna ukraińsko-polskorosyjska, ponieważ rodzaj władzy politycznej kraju agresora, w tym przypadku Rosji, nie może zastąpić głównego, narodowego wymiaru konfrontacji totalitarnej Rosji z demokratyczną Ukrainą. Udział w wojnie Ukraińskiej Republiki Ludowej i Rzeczypospolitej Polskiej przeciwko bolszewickiej Rosji ukraińskiego rządu radzieckiego i odpowiednich struktur wojskowo-politycznych po stronie bolszewików nie może zrównoważyć decydującej roli władz rosyjsko-bolszewickich w wojnie, zwłaszcza że rząd radziecki na Ukrainie był tylko marionetką w rękach czerwonej Moskwy.

W ostatnich dziesięcioleciach historiografia wojny 1920 r. z Rosją Sowiecką została znacznie uzupełniona zarówno przez ukraińskie i polskie badania naukowe, jak i publikacje źródeł ${ }^{1}$. Specyfika dorobku historiograficznego oraz wykorzystanie przez autora nowych źródeł pozwalają

\footnotetext{
${ }^{1}$ Vide: С. Литвин, Симон Петлюра у 1917-1926 роках. Історіографія та джерела: Монографія, Київ 2000, 464 с.; С. Литвин, Суд історії: Симон Петлюра і петлюріана, Київ 2001, 640 с.; А. Руккас, Разом 3 польським військом. Армія Української Народної Республіки 1920 р. (структура, організація, чисельність та уніформа), Ніжин 2013, 464 с.; Директорія, Рада Народних Міністрів УНР, 1918-1920: Документи і матеріали, 3 ч.: у 2 т.; відп. ред. і кер. упоряд. В. Верстюк, Київ 2006, т. 1, 687 с., т. 2, 744 с.; kontynuacja publikacji źródeł zainicjowanych przez diasporę ukraińską w Stanach Zjednoczonych Ameryki - C. Петлюра, Статті. Листи. Документи; упоряд. В. Сергійчук, Київ 1999, т. 3, 614 с.; С. Петлюра, Статті. Листи. Документи; упоряд. В. Сергійчук, Київ 2006, т. 4, 706 с.; М. Омелянович-Павленко, Спогади командарма (1917-1920); упоряд. М. Ковальчук, Київ 2007, 608 с.; Українська революція 1917 - 1921 років у волянсіях: зб. документів; уклав О. Надтока, Київ 2018, 281 с. та інші. J. Cisek, Rok 1920. Wojna polskobolszewicka, Warszawa 2010, 172 s.; L. Wyszczelski, Wojna Polsko-Rosyjska 1919-1920, Warszawa, 2010, 1478 s.; A. Zamoyski, Warszawa 1920. Nieudany podbój Europy przez Lenina, Kraków 2016, 292 s.; J.-K. Maciejewski, Zawadiaka. Dzienniki frontowe 1914-1920, Warszawa 2015, 400 s.; M. Lepecki, W blaskach wojny. Wspomnienia z wojny polsko-bolszewickiej, Warszawa 2017, 220 s. i inni.
} 
zidentyfikować cel niniejszego opracowania - porównanie interpretacji wojny przez jej uczestników ze strony ukraińskiej, polskiej i rosyjsko-bolszewickiej, a także ujawnienie specyfiki polskiego kierunku propagandy bolszewickiej. Wśród zastosowanych metod badawczych są metoda analizy treści (analiza treści tekstów źródłowych), metoda wyznaczania parametrów ilościowych, metoda porównania, ujawnienie wewnętrznej struktury aparatu propagandowego armii rosyjsko-bolszewickiej jako odrębnego obszaru wojskowych wysiłków organizacyjnych, metoda lokalizacji ośrodków publikowania materiałów propagandowych bolszewików, identyfikacja charakterystycznych metod propagandy rosyjsko-bolszewickiej i cechy tej propagandy.

Stosunki między ukraińskimi i polskimi państwami epoki rewolucyjnej miały okresy konfrontacji i współpracy. Konfrontacja w wyniku zderzenia interesów dwóch rewolucji narodowych i dwóch wariantów formowania granic między Ukrainą a Polską oraz współpracy podczas wojny z największym wrogiem nowych państw narodowych - Moskwą, która została ozdobiona nowymi czerwonymi rewolucyjnymi kolorami. Okres działań wojennych między Ukrainą a Polską trwał od listopada 1918 r. do lipca 1919 r., kiedy Ukraińska Armia Galicyjska (UGA) wycofała się poza rzekę Zbruch na Wielką Ukrainę pod presją przeważających sił polskich. Sojusz wojskowy między krajami i wspólna walka z rosyjską armią bolszewicką trwały od kwietnia do listopada 1920 r., to znaczy od czasu podpisania konwencji wojskowej 24 kwietnia i odpowiedniego rozpoczęcia ofensywy armii polsko-ukraińskiej na terytorium okupowanym przez bolszewików Ukraińskiej Republiki Ludowej (UNR) i do zawieszenia broni polsko-rosyjskiej i walk rosyjsko-ukraińskich w listopadzie 1920 r., kiedy front ustabilizował się wzdłuż rzek Zbruch i Słucz.

Interesy UNR zostały zignorowane przez sojusznika wojskowo-politycznego, a Polska uznała legalność tzw. Ukrainy Radzieckiej, to znaczy uznała okupację Ukrainy przez Armię Czerwoną i zniszczenie UNR. Z kolei Polska otrzymała uznanie od bolszewickiej Rosji nowych granic już z ziemiami ukraińskimi Wschodniej Galicji, Wołynia, ukraińsko-białoruskich terytoriów Polesia Zachodniego. Późniejsza historia Drugiej Rzeczypospolitej Polskiej świadczyła o fatalnym błędzie zgody na likwidację UNR jako jedynego prawdziwego sojusznika wojskowego Polski w konfrontacji z bolszewicką Moskwą i utworzenia bezpośredniej granicy polsko-radzieckiej. Wybuch II wojny światowej i napaść na Polskę przez Niemcy Hitlera i Czerwoną Rosję zeznały, że Polacy zostali sami w obliczu śmiertelnego zagrożenia. Sojusznicza Armia UNR dawno już minęła, ponieważ nie było takich dowódców alianckiej armii ukraińskiej jak generał Marko Bezruchko (1883-1944). Szósta dywizja gen. Bezruchka w okresie sierpień-wrzesień 1920 r. bohatersko broniła Zamościa i wniosła znaczący wkład w pokonanie bolszewickiej armii Tuchaczewskiego-Budionnego.

Ukraińskie i polskie interpretacje wojny $z$ bolszewicką Rosją.

Wspólna polsko-ukraińska kampania wyzwoleńcza na Ukrainie w 1920 r. przeciwko okupantowi moskiewskiemu została opisana w apelach Armii UNR do Ukraińców z kilkoma akcentami:

1) obecne wydarzenia były kontynuacją trzyletniej walki o niepodległość państwa ukraińskiego, a mianowicie niepodległości Ukraińskiej Republiki Ludowej;

2) Ukraina była wspierana / uznawana przez Polskę i Litwę;

3) sytuacja Ukrainy w warunkach okupacji moskiewskiej i wrogich działań Armii Czerwonej została przedstawiona w realistyczny sposób - jako „panowanie śmierci i ruiny”;

4) utworzenie silnej, regularnej armii było jedynym wyjściem dla ustanowienia porządku i pokoju, „chroniącego cały lud”. Kluczowymi hasłami w tym zakresie były: „przygotuj się na mobilizację", „dołącz się do ochotniczej armii "”.

W czasie wspólnej ofensywy przeciwko armii rosyjsko-bolszewickiej na Ukrainie rewolucja ukraińska i życie narodowe zostały zniszczone przez siły moskiewskie i zdrajców. Najbardziej radykalne cechy tego zjawiska znajdują się w apelach organu kierującego powstańczym ruchem ukraińskim w obwodzie kijowskim - Komitetu Bolszewickiego (powołanego nie później niż w kwietniu 1920 r.). Obraz walki z okupantem przedstawia dychotomia konfrontacji dobra ze złem, życia i śmierci - zarówno w sferze fizycznej, jak i duchowej. Było wezwanie do powstania ludowego jako zemsty - ,za nasz kościół, zniszczony przez Moskali i Żydów, za krzywdy ludu, za wolności Ukrainy, za mękę i śmierć naszych braci, ojców i synów, za skalanie naszych żon i córek, za rabunek majątków utrzymywanych przez ciężką i ciągłą pracę, za zniewolenie nasze - śmierć dla wszystkich

\footnotetext{
1 Громадяне Української Народної Республіки! Листівка, [w:] О. Надтока (упоряд.), Українська революція 1917 - 1921 років у волянсіях: зб. документів, Київ 2018, с. 184.
} 
zajd moskiewskich ${ }^{1}$. Taka determinacja walki jako przeciwdziałanie totalnemu zniszczeniu i przemocy przez wroga była bolesnym i krwawym rezultatem okupacji Ukrainy oraz wynikiem nieludzkiej brutalności władz sowieckich wobec wszystkich grup ludności na Ukrainie.

Interpretację kampanii wyzwoleńczej przeciwko czerwonej Rosji i jej zwolennikom na Ukrainie przez przywódców Pzreczypospolitej Polskiej można prześledzić na przykładzie apelu do narodu ukraińskiego Wodza Naczelnego Wojsk Polskich Józefa Piłsudskiego (1867-1935) i adresu do mieszkańców Kijowa dowódcy Armii Polskiej generała Edwarda Śmigłego-Rydza (1886-1941) (kwiecień-maj 1920 r.). Apele te potwierdzają fakt okupacji Ukrainy i „ludności ziem tych czynią wiadomym, iż wojska polskie usuną z terenów, przez Naród Ukraiński zamieszkałych, obcych najeżdżców, przeciwko którym lud Ukraiński powstawał z orężem w ręku, broniąc swych sadyb przez gwałtem, rozbojem i grabieżą". Podkreślono, że postęp polskiej armii w głąb Ukrainy opiera się na umowie między rządami polskim i ukraińskim, a sama kampania idzie $\mathrm{w}$ parze $\mathrm{z}$,szeregami walecznych jej synów pod wodzą Atamana Głównego Symona Petlury które w Rzeczypospolitej Polskiej znalazły schron i pomóc w najcięższych dniach próby dla ludu ukraińskiego". W apelu podkreślono również, że celem kampanii jest nie tylko wyzwolenie Ukrainy z władzy jeźdźca i wypełnienie przez Polskę „szczytnego zadania walki o Wolnośc Ludów”, ale także „aby władze państwowe ukraińskie stworzyły Wam kulturalne, praworządne warunki bytu, oparte na ładzie, bezpieczeństwie mienia i życia spokoju i porządku"2.

Krótko po wyzwoleniu Kijowa - 9 maja 1920 r., w swoim przemówieniu do mieszkańców stolicy Ukrainy generał porucznik Edward Śmigłe-Rydz otwarcie ujawnił stosunek Polaków do władz bolszewickich, mówiąc, że „polskie wojska przyszły, by uwolnić Wasz Kraj od najazdu barbarzyństwa i bezprawia bolszewickiego"3.

Skala rosyjsko-bolszewickiej propagandy i struktura aparatu propagandowego.

Praca propagandowa bolszewików podczas wojny polsko-ukraińsko-rosyjskiej 1920 roku powinna być określona jako propaganda specjalna. Miało to na celu zapewnienie w umysłach przeciwnika wojskowego i różnych grup ludności na okupowanych terytoriach niezbędnej interpretacji wydarzeń i cech. Jako wysiłki propagandowe bolszewików miały usprawiedliwić rosyjską armię okupacyjną i potęgę sowiecką wręcz przeciwnie, aby skompromitować polsko-ukraiński sojusz wojskowo-polityczny i ideę kampanii wyzwoleńczej, jednocześnie wysiłki te musiały zagrozić polskoukraińskiemu sojuszowi wojskowo-politycznemu i idei kampanii wyzwoleńczej, ta propaganda musiała być znacząca. Chodziło o zaprzeczenie oczywistemu i podważenie szlachetnego pragnienia wolności dla narodu ukraińskiego walczącego o wolność. Rosyjska specjalna propaganda spełniała to kryterium dopasowania skali kłamstwa do właściwej skali propagandy. Na podstawie zbioru bolszewickich ulotek propagandowych w języku polskim (kwiecień-wrzesień 1920 r.) Wydziału Starych Wydań Drukowanych Biblioteki Narodowej Ukrainy imienia W. Wernadskiego, które składają się z 67 różnych tytułów, prześledźmy te cechy.

Wśród bolszewickich władz politycznych i afiliowanych struktur polskich i departamentów politycznych w Armii Czerwonej, które przeprowadziły specjalne działania propagandowe przeciwko polsko-ukraińskiej kampanii wyzwoleńczej, znalazły się: Wszechrosyjski Centralny Komitet Wykonawczy Rad robotniczych, włościanskich i żołnierskich delegatów ${ }^{4}$, Wojenno-Rewolucyjna Rada Respubliki Rad, Komisariat Ludowy do spraw wojennych Respubliki $\operatorname{Rad}^{5}$, Komitet Wykonawczy Międzynarodówki Komunistycznej ${ }^{6}$, Wojenna Rada Rewolucyjna XII Armji ${ }^{7}$, Wydział

\footnotetext{
${ }^{1}$ Відозва до українського народу Комітету боротьби з більшовизмом. Листівка, [w:] Ibidem, c. 177.

2 J. Piłsudski, Do wszystkich mieszkańców Ukrainy. До всіх жителів України. Листівка, [w:] О. Надтока (упоряд.), Українська революція 1917 - 1921 років у волянсіях: зб. документів, Київ 2018, с. 178; Е. Smigły Rydz, Do mieszkańców m. Kijowa. До мешканців м. Києва. Листівка, [w:] Ibidem, с. 185.

${ }^{3}$ E. Śmigły Rydz, Do mieszkańców m. Kijowa. До мешканців м. Києва. Листівка, [w:] Ibidem, с. 185.

4 Żołnierze, robotnicy i włoścjanie Polski! Towarzysze! Rząd Polski rozpoczął wojne przeciw sowieckim republicom Rosji i Ukrainy. Ulotka, b.m. 1920, 2 s.

${ }^{5}$ Rozkaz Przewodniczący Wojenno-Rewolucyjnej Rady Respubliki, Komisarz ludowy do spraw wojennych L. Trockij. Zołnierze Polscy! W chwili - kiedy w tej wychwalanej przez burżuazje Najjaśniejszej Rzeczypospolitej Polskiej. Ulotka, b.m. 1920, 1 s.

${ }^{6}$ Do proletarjuszy wszystkich krajów. Robotnicy wszystkich krajów! Na wschodzie znowu krew się leje. Ulotka, b.m. 1920, 2 s.

${ }^{7}$ Zołnierzu i robotniku polski! Od ciebie zależy zaprzestanie dalszej bratobójczej walki! Ulotka, b.m. 1920, 1 s.
} 
Polityczny Rewolucyjnej Rady Wojennej XII Armji ${ }^{1}$, Polske biuro przy Wydziału Politycznym Rewolucyjnej Rady Wojennej XII Armji ${ }^{2}$, Politoddział X-tej Dywizji Armji Czerwonej ${ }^{3}$, Sekcja Polska Grupy Międzynarodowej Propagandy Polituprawlenja Narkomwojenu ${ }^{4}$, Tymczasowy Komitet Rewolucyjny Polski ${ }^{5}$, Warszawska Rada Delegatów Żołnierskich ${ }^{6}$.

Z listy wynika, że istniało co najmniej jedenaście różnych rosyjsko-bolszewickich struktur wojskowo-politycznych i stowarzyszonych polskich organizacji propagandowych. Skalę i poziom propagandy specjalnej można zobaczyć na przykładzie ulotek, wydanych w czerwcu $1920 \mathrm{r}$. w celu osłabienia polskiej armii podczas ofensywy Armii Czerwonej. Z wyznaczonej kolekcji ulotek bolszewickich w języku polskim w okresie kwiecień-wrzesień 1920 r. tylko w czerwcu wydano 10 różnych wydań $\mathrm{z}$ apelem do polskiego wojska. Ustalono, że tylko dwie edycje tych ulotek miały łączny nakład co najmniej 60000 egzemplarzy ${ }^{7}$. Kwota ta powinna wystarczyć na pokrycie całej polskiej armii specjalnym materiałem propagandowym, ponieważ na terytorium Ukrainy przebywało do 50000 polskich żołnierzy, jak zauważył badacz postaci Symona Petlury, ukraiński historyk Sergij Lytwyn $^{8}$. Dlatego wszelki możliwy obieg tych dziesięciu wydań w czerwcu $1920 \mathrm{r}$. był prawdziwym atakiem informacyjnym, co miało wpłynąc na stan moralny i psychologiczny polskich legionistów. Był to jeden z przykładów rosyjsko-bolszewickiej specjalnej techniki propagandowej, która polegała na organizowaniu masowych wpływów propagandowych za pomocą stacjonarnych i mobilnych centrów drukarskich oraz przygotowanej strukturze do rozpowszechniania tych publikacji.

Ulotki zostały wydrukowane w Kijowie (przede wszystkim), Charkowie, Odessie, Równo, bliżej linii frontu w pociągu - mobilne centrum drukowania, a także w Białymstoku i potajemnie w w Warszawie (wariant dezinformacji dotyczący publikacji ulotek $\mathrm{w}$ Warszawie w celu zdemoralizowania polskiego wojska jest możliwy) ${ }^{9}$. Propaganda ta została rozpowszechniona wśród polskich wojskowych i cywilów na Prawobrzeżnej Ukrainie w Polsce przez same siły wojskowe. Jednostki Armii Czerwonej Frontu Południowo-Zachodniego, która walczyła na Ukrainie i dalej we wschodniej Polsce, otrzymały pewną liczbę ulotek a ta informacja była czasem zapisywana na jednej z ulotek, wskazując numer aktu odbioru, datę i liczba ulotek ${ }^{10}$. W propagandę zaangażowani byli

\footnotetext{
${ }^{1}$ Cóż, warto się o to bić, towarzyszu legionisto? Dziś, gdy wojna domowa... Ulotka, b.m. 1920, $1 \mathrm{~s}$.

${ }^{2}$ Żołnierze Polscy chłopi i robotnicy! Dla jaśniepanów polskich wybiła ostatnia godzina... Ulotka, b.m. 1920, 1 s.

3 Trzecia Międzynarodówka (Międzynarodowe stowarzyszenie robotników). Co to jest Międzynarodówka? Ulotka, b.m. 1920, 1 s.

${ }^{4}$ Robotnicy Polacy! Wszechświatowa wojna imperialistyczna, która zdziesiątkowała lud roboczy i włościański... Ulotka, Kijów 1920, 1 s.

${ }^{5}$ Do Włościan Polskich. Armja Czerwonej Rosji robotniczej wkraczyła na ziemię polską. Ulotka, Białystok $1920,1 \mathrm{~s}$.

6 Warszawska Rada delegatów żołnierskich. Żołnierze w odpowiedzi Piłsudskiemu! Naczelnika i Wodza Kapitalistycznej Polski! Ulotka, Warszawa 1920, 1 s.

${ }^{7}$ Zgodnie z napisami na ulotkach liczba otrzymanych kopii - Rozkaz Przewodniczący Wojenno-Rewolucyjnej Rady Respubliki, Komisarz ludowy do spraw wojennych L. Trockij. Zołnierze Polscy! W chwili - kiedy w tej wychwalanej przez burżuazje Najjaśniejszej Rzeczypospolitej Polskiej., b.m. 1920. Ulotka, s. 1 (21 tysięcy egzemplarzy); Do proletarjuszy wszystkich krajów. Na wschodzie znowu krew się leje... Ulotka, b.m. 1920, s. 1 (39 tysięcy egzemplarzy).
}

${ }^{8}$ C. Литвин, Петлюра і Пілсудський: спільний похід на Київ 1920 року, http://www.reibert.info/threads/petlura-i-pilsudskij-pohid-na-kijiv-1920-roku.213217.html, 16.12.2011.

9 Robotnicy-Polacy! Ciężkie jarzmo rządów krwawej szlachty polskiej zaciężyło na pewien czas i nad Kijowem... Ulotka, Kijów 1920, 1 s.; Rozkaz. Doszło do wiadomości Politycznego Wydziału N-tej Armji, że ciemne indywidua... Ulotka, Równo 1920, 1 s.; Do dymisji! Rząd pana Skulskiego, Patka... rząd winowajców wojny z RepublikamiSowieckiemi podał się do dymisji. Ulotka, Charków 1920, 1 s.; Drodzy bracia zołnierze Polscy! Oto znów, wierząc w oszukaństwa i obiecanki... Ulotka, Odessa 1920, 1 s.; Żołnierze! Bracia! Towarzysze! Płatni pismacy, wysługujący się za judaszowe srebrniki kapitalistom i bankierom... Ulotka, Pociąg drukarnia Polit. Wydziału N-skiej Armji 1920, 1 s.; Rozkaz № 11. Żołnierze Polscy! Wszelkie dalsze prowadzenie wojny jest zbrodnią wobec całego ludu pracującego Polski. Ulotka, Białystok 1920, 1 s.; Warszawska Rada delegatów żołnierskich. Żołnierze w odpowiedzi Piłsudskiemu! Naczelnika i Wodza Kapitalistycznej Polski! Ulotka, Warszawa 1920, 1 s.

${ }^{10}$ Tak, jedna z jednostek wojskowych Armii Czerwonej 1 lipca 1920 r. otrzymała od kierownictwa politycznego frontu południowo-zachodniego 1000 egzemplarzy ulotki „Do proletarjuszy wszystkich krajów”, wydana w maju 1920 r., zbiorowy autor odwołania został oznaczony Komitet Wykonawczy Międzynarodówki Komunistycznej (Vide: Do proletarjuszy wszystkich krajów. Robotnicy wsystkich krajów! Na wschodzie znowu krew się leje. Ulotka, b. m. 1920, s. 1). 
pracownicy Ukraińskiej Komisji Nadzwyczajnej (Komisja została założona 3 grudnia 1918 r. jako oddział Rosyjskiej Komisji Nadzwyczajnej w celu zwalczania kontrrewolucji, spekulacji, sabotażu i przestępstw służbowych ${ }^{1}$ ), pracownicy Rosyjskiej Komisji Nadzwyczajnej, a także jednostki wojskowe wymienionych sowieckich organów karnych. Podczas wojny polsko-ukraińsko-rosyjskiej w 1920 r. przewodniczący Rosyjskiej Komisji Nadzwyczajnej Felix Dzierżyński był bezpośrednio zaangażowany w tworzenie przyszłego polskiego rządu radzieckiego i był zastępcą, ale w gruncie rzeczy był prawdziwym liderem stworzonego marionetkowego wojskowo-politycznego organu zarządzającego Tymczasowego Komitetu Rewolucyjnego ${ }^{2}$ ). Komitet w zajętym przez bolszewików polskim Białostoku wydrukował rozkazy dla polskich żołnierzy, przeciwko którym walczył (!), licząc na dalsze przejęcie władzy nad całą Polską wraz $\mathrm{z}$ rozwojem światowej rewolucji, ale $\mathrm{w}$ rzeczywistości w trakcie dalszej interwencji rosyjsko-bolszewickiej w krajach europejskich. Wyraźni i ukryci bolszewiccy agenci wśród Polaków, reprezentowani organizacyjnie przez wspomnianą Sekcją Polską Grupy Międzynarodowej Propagandy Polituprawlenja Narkomwojenu Rosji, Tymczasowy Komitet Rewolucyjny Polski, Polskie biuro przy Wydziału Politycznego Rewolucyjnego Rady Wojennej XII Armji, tak zwaną Warszawską Radą Delegatów Żołnierskich, dodatkowo wzmocnili rozwiniętą strukturę specjalnych organów propagandowych rosyjskich władz radzieckich. Pionowo system organizacji propagandy osiągnął poziom wyższych władz bolszewików, w szczególności Wszechrosyjskiego Centralnego Komitetu Wykonawczego Rad robotniczych, włościanskich i żołnierskich delegatów, Wojenno-Rewolucyjnej Rady Respubliki Rad, Komisariatu Ludowego do spraw wojennych Respubliki Rad, a na niższych poziomach system obejmował specjalne struktury polityczne lub komisarzy w jednostkach wojskowych oraz jednostki komunistów i zwolenników na poziomie lokalnym wraz z oddolną siecią agentów bolszewików. Głównym organem specjalnej propagandy w całym departamencie wojskowym Rosji Radzieckiej było Polituprawlenie Narkomwojenu oraz Zarząd Polityczny Ludowego Komisariatu Wojskowego.

\section{Sensowne napelnianie i metody specjalnej propagandy rosyjsko-bolszewickiej.}

Bolszewicka interpretacja wojny 1920 została przedstawiona w wersji uogólnionej w wydaniu Komitetu Wykonawczego Międzynarodówki Komunistycznej „Do Proletarjuszy wszystkich krajów"'. Główny konstrukt propagandowy - pragnienie pokoju w bolszewickiej Rosji i agresywność Polski, uwarunkowany agresywną naturą samego systemu kapitalistycznego. Był to wielki błąd dla potencjalnych zwolenników idei bolszewickiej lub komunistycznej, który stał się jednym z fundamentów alternatywnej rzeczywistości stworzonej przez rosyjsko-bolszewicką propagandę i który wspierał istnienie moskiewskiego więzienia narodów i jego prozelitów na świecie. Kraj, który formalnie przestrzegał strategii rewolucji światowej od 1917 r., kierowany przez bezprawną władzę, która zapewniła nową drogę rozwoju politycznego poprzez rewolucję i straszne represje, agresor i zawodowy kata $\mathrm{w}$ tej alternatywnej rzeczywistości stał się czymś przeciwnym, odwracając obraz dobra i zła, stał się zwolennikiem pokoju i wsparciem humanizmu w manipulacyjnej wersji ochrony uciśnionych! W związku z tym reszta świata, która próbowała powstrzymać tę chorobę zniszczenia i zła - w oparciu o wartości chrześcijańskie i narodowe, stał się światem wiecznych drapieżników, wyzyskiwaczy, którzy zasłużył tylko na zniszczenie. Było to świetne znalezisko ideologicznego frontu bolszewików, które przewidywało możliwość stworzenia alternatywnej rzeczywistości dla pełnej rehabilitacji samego zła. Nastąpiła rewolucja znaczeń - zło stało się dobrem i postępem, a dobro stało się złem i odrazą. W najlepszym razie dobro stało się anachronizmem. Wysokie cele walki narodów, w szczególności narodu ukraińskiego i polskiego, zostały uciszone i zdyskredytowane przede wszystkim poprzez stworzenie negatywnego obrazu przywódców walki narodowej, zatwierdzanie

\footnotetext{
${ }^{1}$ В. Сташис, Всеукраїнська надзвичайна комісія по боротьбі з контрреволюцією, спекуляцією, саботажем та службовими злочинами [w:] М. Бажан (голова редкол.), Українська радянська енциклопедія, Київ 1978 , т. 2, c. 418.

${ }^{2}$ Tymczasowy Komitet Rewolucyjny Polski istniał od 30 lipca do 20 sierpnia 1920 r. Nominalnym szefem tej marionetkowej struktury rządowej była postać polskiego ruchu socjaldemokratycznego Julian Marchlewski, jego zastępca był szefem Wszechrosyjskiej Komisji Nadzwyczajnej, organizatora Czerwonego Terroru Feliks Dzierżyński (Vide: Rozkaz № 11. Żołnierze Polscy! Wszelkie dalsze prowadzenie wojny jest zbrodnią wobec całego ludu pracującego Polski. Ulotka, Białystok 1920, s. 1; Do Włościan Polskich. Armja Czerwonej Rosji robotniczej wkraczyła na ziemię polską. Ulotka, Białystok 1920, s. 1).

${ }^{3}$ Do proletarjuszy wszystkich krajów. Robotnicy wsystkich krajów! Na wschodzie znowu krew się leje. Ulotka, b. m. 1920, s. 1-1 zwr.
} 
negatywnych skojarzeń semantycznych lub wirusów werbalnych (od łacińskiego verborum virus trucizna werbalna).

Kilka tez szczegółowo opisujących bolszewicką interpretację wojny z siłami narodowymi Polski i Ukrainy:

1. Polska na propozycje pokojowe rządu Sowieckiego odpowiedziała zdradzieckim napadem na Ukrainę; napad ten prowadzi ona pod hasłem przywrócenia władzy Petlury, awanturnika, który sprzedawał się to kapitalistom Koalicji, to znowu imperjalistom niemieckim i który wreszcie teraz, gdy robotnicy i włościanie Ukrainy pozbawili go władzy, sprzedał się obszarnikom polskim (znaczące powiązania, a jednocześnie wirusy werbalne - Rosja dąży do pokoju, Polska zdradziecka i szuka wojny, Petliura jest zwykłym poszukiwaczem przygód; czasami bolszewicy używali prawie inteligentnych definicji, ale sama treść odwołania sugerowała surowsze definicje, które podano dalej; Petliura sprzedał się i sprzedał Ukrainę - główny wirus werbalny rosyjskich bolszewików dotyczący postaci głównego wojownika z bolszewizmem wśród Ukraińców w tym czasie - Głównego Atamana Armii UNR Simona Petliury).

2. Polska rozpoczęła wojne w celu ograblienia włościan ukrainskich oraz oddania ich ziemi obszarnikom polskim.

3. Polska walczy o to, by narzucić Rosji Sowieckiej, zrujnowanej przez napastujących ją kapitalistow koalicyjnych, ogromną kontrybucję.

4. Od was, robotnicy wszystkich krajów, będzie zależało, żeby wojna ta w jaknajkrótszym czasie została zakonczona pogromem polskich kapitalistów i obszarników.

Na końcu apelu Komitetu Wykonawczego Międzynarodówki widzimy hasła potrzeby walki polskich robotników z własnymi polskimi władzami i proletariackiej rewolucji światowej - „Do szturmu więc, robotnicy Polscy! Rozpoczyna się wasz ostatni bój. Zbliża się dzień w którym sędzami będziemy my"1.

W sprawie praw narodów, ich walki o państwowość w obliczu upadku Rosji jako imperium, bolszewicy stosowali odrębną metodologię. Niemożność przypisania tej kwestii sprawie kontrrewolucyjnej i, w tym przypadku, powtórzenia szowinistycznej polityki carskiej Rosji, zmusiła bolszewików do ucieczki się do pewnych kompromisów, dopuszczając ograniczone prawo krajowe. W rzeczywistości było to prawo do republik narodowych bez niezależnych narodów, prawo do sfałszowania formacji narodowych bez elity narodowej, do formalnej egzystencji bez narodowego mitu i narodowej przyszłości. Dlatego dyskredytowanie przywódców narodowych było jednym z głównych segmentów rosyjsko-bolszewickiej propagandy. Widzimy to na przykładzie lidera UNR Simona Petlury i głowy państwa polskiego Józefa Piłsudskiego. Postać Petliury została zdyskredytowana przez oszczerstwo, że ten poszukiwacz przygód sprzedał się obcokrajowcom (wśród Polaków bolszewicy szerzyli te same kłamstwa na temat Simona Petliury, jak to robili z Ukraińcami w ulotkach Petluru nazywali „,zaprzysięgłym handlarzem Ukrainy, którą gotów jest sprzedać każdemu kto mu dobrze zapłaci”"2), postać Piłsudskiego została również zdyskredytowana z powodu kłamstw dotyczących jego historii służenia innym (sic!). Były socjalista, a już w 1920 r. „najmita sprzymierzonego kapitału” (czyli kapitału Entente), „którą zaprzedał się giełdziarom francuskim”3.

W propagandzie i różnych wpływach na tych terytoriach i na tych, którzy mieli stać się przedmiotem ekspansji rosyjsko-bolszewickiej, Czerwoni szowiniści stosowali zasadę starego państwa carskiego dotyczącą powszechnego stosowania struktur partnerskich do ekspansji rosyjskiej. Kiedyś była to Cerkiew Prawosławna i organizacje Moskwofilskie / Słowianofilskie, w ostatnim czasie była już sekta cywilna Trzeciej Międzynarodówki oraz organizacje Partii Socjaldemokratycznej / Komunistycznej. Okupacja Ukrainy przez rosyjskich bolszewików pokazała agresorowi rzeczywistość koncepcji rewolucji światowej i realizm mocy bagnetów dalej na zachód od głodnej Moskwy. Po rozbiciu Ukraińskiej Republiki Ludowej Rzeczpospolita miała stać się kolejną ofiarą rosyjskiego wyzwolenia i kolejnym krokiem w światowej misji proletariatu.

\footnotetext{
${ }^{1}$ Do proletarjuszy wszystkich krajów. Robotnicy wsystkich krajów! Na wschodzie znowu krew się leje. Ulotka, b. m. 1920, s. 1 zwr.

${ }^{2}$ Hultajska czwórka. Jaśnepan marszałek Piłsudski, ataman hajdamacki Petlura, han krymski baron Wrangiel i partyzant bat'ko Machno zmówili się przeciw rządom robotniczo-włościańskim w Rosji i na Ukrainie. Ulotka, b. m. 1920, s. 1 zwr.

${ }^{3}$ Ibidem, s. 1 .
} 
Wśród metod specjalnej propagandy zauważamy także zasadę łączenia w tekstach propagandowych mniejszego losu prawdy z większym losem kłamstw. W różnych okolicznościach odsetek prawdy i fałszu może się różnić, ale główną zasadą było osiągnięcie większej perswazji informacji, jeśli informacje zawierały co najmniej kilka przykładów prawdziwych faktów. Najprostszym schematem było użycie kilku oczywistych faktów zewnętrznych i wypełnienie treści całkowicie fałszywymi informacjami w odmianach różnych składników - dezinformacja, milczenie o prawdziwym stanie rzeczy, dezorientacja i podżeganie do sprzeczności, dyskredytacja przeciwników i otwarte kłamstwa ${ }^{1}$. Na przykład przeanalizujmy apel do polskich legionistów w maju $1920 \mathrm{r}$. „Towarzysze Legjoniści”, apel sporządzony przez rosyjsko-bolszewickie struktury polityczne w imieniu żołnierzy Armii Czerwonej. Powód odwołania był prawdziwy - dzień 1-go Maja, który został przedstawiony jako „dzień solidarności robotniczej, dzień łączności całego proletarjatu międzynarodowego”. Teza, choć względna, dotycząca legionistów jako „synów robotników i włościan polskich" jest również uzasadniona. I prawdziwe było twierdzenie autorów proklamacji, że w maju 1920 r. polskie wojsko nie walczyło o swoje ziemie ${ }^{2}$. Te prawdziwe dane zostały również wykorzystane do przekazania pomysłów potrzebnych bolszewickim władzom, dla pewnego rodzaju przeformatowania świadomości. Korzystanie z zasady manipulacji (z łac. manipulare - rządzić) percepcji publicznej (z perspektywą wpłynięcia na ogólną świadomość społeczną), odnosząc się do pierwotnego prawdziwego faktu, pewna konstrukcja została zbudowana w formie przewróconej piramidy. W sercu wiadomości znajduje się prawdziwy fakt, powyżej znajdują się niezbędne bloki, które rozszerzają wiadomość, bloki informacyjne obejmują szerszy zakres pomysłów, osobowości, procesów i tworzą szeroką platformę kłamstw, które z pozoru logicznie wyrosły z tego prawdziwego faktu! Na przykład na podstawie tezy o pochodzeniu roboczym i chłopskim większości zwykłych żołnierzy polskiej armii powstaje zrozumienie specyfiki tego środowiska, powstaje specjalna świadomość, która została zapisana w specjalnej definicji - świadomość klasowa. W tekście tej ulotki oficerowie polskiej armii i przywódcy państwowi Polski są nieustannie określani jako szlachta, „jaśniepany”, służąca interesom kapitału europejskiego (zwłaszcza Francji), to znaczy są innymi i mają inne interesy. Jednocześnie rosyjsko-bolszewicka armia, radziecka Rosja i radziecka Ukraina są przedstawiane jak spokrewnione, nie obce, ponieważ interesy robotników i chłopów są tam „chronione”. Na koniec logicznego rozumowania wniosek jest taki, że musimy współpracować z bolszewikami Rosjanami i Ukraińcami, którzy mają powiązane interesy i odpowiednią świadomość klasową. Zamiast tego ich własny rząd, dowódcy, Ukraińcy dowodzeni przez Petliurę nie są wiarygodni i ogólnie mogą być postrzegani jako wrogowie. Apel do polskich legionistów zakończył się hasłami - „w dzień jednoczący cały proletarjat międzynarodowy, wzywając was do zaprzestania walki i połączenia się z nami, pozdrawiamy was dawnym okrzykiem bojowym: Niech żyje rewolucja! Precz z wojną! Niech żyje Robotniczo-Włościańska Polska! Niech żyje Robotniczo-Włościańska Rosja i Ukraina!”3. Początek i koniec myśli bez manipulacyjnych „logicznych” połączeń powinien wyglądać mniej więcej tak: jeśli jesteś synem robotnika lub chłopa, musisz stać się zdrajcą Ojczyzny, musisz odmówić wykonania rozkazów dowódców, pozostawić armię bez upoważnienia i przygotować się do walki z własnym rządem po stronie bolszewików i ich sojuszników! Jednak ten prawdziwy obraz został ukryty za inną ,prawdą" - prawdą moskiewskiego agresora.

W ulotce „Koledzy i towarzysze - żołnierze Polscy!”, opracowanej przez Wydział Polityczny Rewolucyjnej Rady Wojennej N-tej Armji (prawdopodobnie XII-tej Armji), widzimy próbę zastosowania metody absolutnej oczywistości - dostarczone informacje mają na celu ewentualną weryfikację i dalsze postrzeganie. Jest to przykład odwołania do polskiego wojska tych samych polskich legionistów - konkretnych osób o nazwiskach. Stwierdzono, że pozostawili swoje jednostki wojskowe „,z powodów ideologicznych”, „z całą świadomością tego co robimy”, ponieważ uważali „polską reakcję" za najgorszego wroga, wroga polskich robotników i chłopów, do których należały. W

\footnotetext{
${ }^{1}$ Ці методи ведення спеціальної пропаганди залишалися на озброєнні Радянської армії до кінця існування СРCP. Vide: Спогади випускника Військового інституту іноземних мов (BIIM) Міністерства оборони СРСР, командира 109 загону спецпропаганди 66-ї мотострілецької бригади Обмеженого контингенту радянських військ в Афганістані (ОКРВА) Сергія Небренчина «Оружие смыслов и нервов», http://www.clubvi.ru/news/2015/08/04.html, 04.08.2015.

2 Towarzysze Legjoniści. Dziś dzień 1-ego Maja, dzień solidarności robotniczej, dzień łączności całego proletarjatu międzynarodowego. Ulotka, b. m. 1920, s. 1.

${ }^{3}$ Ibidem, s. 1 zwr.
} 
tym opowiadaniu ścieżka do tak haniebnego kroku dla honoru wojskowego jest przedstawiana jako ścieżka wglądu, kiedy otworzyły się oczy, kto jest prawdziwym wrogiem ludu pracującego i że te szacunki Armii Czerwonej, które zostały im kiedyś zaoferowane przez oficerów polskiej armii (podano imiona tych dowódców!) są całkowicie fałszywe. Tak więc, od niedawnych wrogów Armii Czerwonej i Rewolucji, ale wrogów w wyniku przymusu (!), ci zdrajcy przysięgi wojskowej stali się ich „najgorętszymi sprzymierzeńcami”. Tekst opowieści przedstawił historię „braterskiego i serdecznego" przyjęcia tych uciekinierów przez Moskiewską Armię Czerwoną, armia bolszewicka została przedstawiona nie jako „banda szubrawców i oberwańców”, ale „silna i grożna potęga proletarjatu wyzwolonych Republik Sowieckich”, ,ideowi i waleczni obrońcy Rewolucji, bracia nasi i sprzymierzeńcy". Wezwanie do naśladowania ich przykładu podpisało czterech żołnierzy polskiej armii - szeregowiec 42-go piechotnego pułku 18-ej Dywizji Strzelców Kresowych S. Korman, szeregowiec 1-go pułku Konnej artylerji polowej Roman Policzkiewicz, szeregowiec 8-go piechotnego pułku 3-ej Dywizji Legjonów Leon Czerwonobroda i szeregowiec 49-go Lubelskiego piechotnego pułku Adam Langa ${ }^{1}$. Tak więc oprócz testowania metody absolutnej oczywistości, podobnie jak w przypadku metody przewróconej piramidy, zastosowano technikę tworzenia nowej sytuacji poznawczej, gdy żołnierz znajdzie się w sytuacji wyboru i prowadzenia nowej służby - służąc „bliższym” interesom. W tym przypadku - służąc interesom klasy społecznej i własnym interesom, biorąc pod uwagę przynależność do uciskanego środowiska robotników i chłopów. Słaba narodowa i wojskowa świadomość korporacyjna, a także ewentualny brak środków anty-propagandowych w środowisku polskiej armii (lub podobny brak organizacji kontrpropagandowej w armii, z którą walczyła Rosja Radziecka), stworzyło sytuację stopniowego dążenia do nowej opinii społecznej prorosyjskiej, probolszewickiej w kształtowaniu idei "sprawiedliwego społeczeństwa”, „sprawiedliwego porządku świata" - aż do przejścia na stronę wroga.

Winiki wyszukiwania. Interpretacje treści i zadań wojny polsko-ukraińsko-rosyjskiej $1920 \mathrm{r}$. były diametralnie różne przez uczestników konfrontacji. Dla Ukrainy wojna z Moskwą stała się walką o przetrwanie narodu. Walkę z bolszewicką inwazją na Ukrainie przedstawiano jako walkę $\mathrm{z}$ zaciekłym wrogiem, który niesie śmierć fizyczną i duchową. Dla Polski wojna z bolszewicką Rosją była walką przeciwko władzy bez prawa, która zagrażała zarówno Ukraińcom, jak i Polakom. Armia rosyjsko-bolszewicka i to, co przyniosła na bagnety, interpretowane było jako barbarzyństwo, zagrożenie dla wolności, praw, porządku. Wojna Rzeczypospolitej Polskiej przeciwko Rosji Sowieckiej w sojuszu z Ukraińską Republiką Ludową została podkreślona przez przywódców polski jako zdecydowana misja pomocy w walce o wolność narodów.

Ponieważ Rosja Radziecka jako agresor i okupant nie mogła ujawnić prawdziwej sytuacji, główną cechą ofensywy informacyjnej bolszewików było stworzenie alternatywnej rzeczywistości dla dalszej ekspansji na Zachód. W tym fikcyjnym obrazie dla neofitów Rosja usiłowała przedstawić się jako miłujący pokój i obrońca uciśnionych. Sprawców wojny 1920 w bolszewickiej propagandzie nazwano reakcyjną Polską i żądną przygód Petlurą. Bolszewicy, apelują do wojska i ludności cywilnej od czasu aktywnej ofensywy na prawobrzeżnej Ukrainie i dalej w Polsce Wschodniej, coraz bardziej rozpowszechniali ideę rewolucji socjalistycznej na Zachodzie i promowali ideę utworzenia Polskiej Rzeczypospolitej Socjalistycznej.

Wysiłki propagandowe Rosji Radzieckiej stanowiły prawdziwy front ideologiczny i informacyjno-psychologiczny, który został dostarczony przez zaawansowaną strukturę organizacyjną i zarządczą, obejmował bolszewików rosyjskich i związane $\mathrm{z}$ nimi polskie formacje wojskowopolityczne. Na przykładzie kolekcji ulotek bolszewickich w okresie od kwietnia do września $1920 \mathrm{r}$. zidentyfikowano jedenaście takich struktur. Głównym organem specjalnej propagandy w całym departamencie wojskowym Rosji Radzieckiej było Polituprawlenie Narkomwojenu oraz Zarząd Polityczny Ludowego Komisariatu Wojskowego.

Wnioski. Istotnymi cechami propagandy moskiewskiej podczas wojny 1920 roku były jej rozmiary w kategoriach ideologicznych i ilościowych. Bolszewicy polegali na społecznym wymiarze poglądów człowieka, co dawało mu więcej okazji do egoistycznego zainteresowania, niż wymiary religijne i narodowe. Specjalna propaganda organizowana i prowadzona przede wszystkim przez struktury wojskowe pod kontrolą organów politycznych i komisarzy polowych, propaganda

\footnotetext{
1 Towarzysze Legjoniści. Dziś dzień 1-ego Maja, dzień solidarności robotniczej, dzień łączności całego proletarjatu międzynarodowego. Ulotka, b. m. 1920, s. 1 zwr.
} 
przewidywała stworzenie nowej perspektywy społecznej, w której świat dobra i zła zmieniał miejsca, a politykę ekspansji rosyjsko-bolszewickiej przedstawiano jako wyzwolenie narodów. Techniki propagandowe polegały na manipulowaniu świadomością nie tylko poprzez tradycyjne dezinformacje, wzbudzanie sprzeczności w otoczeniu wroga, w kompromitacji wroga, ale także specjalne techniki, które są zdefiniowane jako metody przewróconej piramidy, absolutnej oczywistości i powstania sytuacji kontrolowanego wyboru poznawczego.

\section{REFERENCES}

1. A. Zamoyski, Warszawa 1920. Nieudany podbój Europy przez Lenina, Kraków 2016, 292 s.

2. Cóż, warto się o to bić, towarzyszu legionisto? Dziś, gdy wojna domowa... Ulotka, b.m. 1920, $1 \mathrm{~s}$.

3. Do dymisji! Rząd pana Skulskiego, Patka... rząd winowajców wojny z RepublikamiSowieckiemi podał się do dymisji. Ulotka, Charków 1920, 1 s.

4. Do proletarjuszy wszystkich krajów. Robotnicy wsystkich krajów! Na wschodzie znowu krew się leje. Ulotka, b. m. 1920, 2 s.

5. Do Włościan Polskich. Armja Czerwonej Rosji robotniczej wkraczyła na ziemię polską. Ulotka, Białystok $1920,1 \mathrm{~s}$.

6. Drodzy bracia zołnierze Polscy! Oto znów, wierząc w oszukaństwa i obiecanki... Ulotka, Odessa 1920, 1 s.

7. E. Smigły Rydz, Do mieszkańców m. Kijowa. До мешканців м. Києва. Листівка, [w:] О. Надтока (упоряд.), Українська революція 1917 - 1921 років у волянсіях: зб. документів, Київ 2018, с. 185.

8. Hultajska czwórka. Jaśnepan marszałek Piłsudski, ataman hajdamacki Petlura, han krymski baron Wrangiel i partyzant bat'ko Machno zmówili się przeciw rządom robotniczo-włościańskim w Rosji i na Ukrainie. Ulotka, b. m. 1920, 2 s. .

9. J. Cisek, Rok 1920. Wojna polsko-bolszewicka, Warszawa 2010, 172 s.

10. J. Piłsudski, Do wszystkich mieszkańców Ukrainy. До всіх жителів України. Листівка, [w:] О. Надтока (упоряд.), Українська революція 1917 - 1921 років у волянсіях: зб. документів, Київ 2018, с. 178

11. J.-K. Maciejewski, Zawadiaka. Dzienniki frontowe 1914-1920, Warszawa 2015, $400 \mathrm{~s}$.

12. L. Wyszczelski, Wojna Polsko-Rosyjska 1919-1920, Warszawa, 2010, 1478 s.

13. M. Lepecki, W blaskach wojny. Wspomnienia z wojny polsko-bolszewickiej, Warszawa 2017, $220 \mathrm{~s}$.

14. Robotnicy Polacy! Wszechświatowa wojna imperialistyczna, która zdziesiątkowała lud roboczy i włościański... Ulotka, Kijów 1920, 1 s.

15. Robotnicy-Polacy! Ciężkie jarzmo rządów krwawej szlachty polskiej zaciężyło na pewien czas i nad Kijowem... Ulotka, Kijów 1920, 1 s.

16. Rozkaz № 11. Żołnierze Polscy! Wszelkie dalsze prowadzenie wojny jest zbrodnią wobec całego ludu pracującego Polski. Ulotka, Białystok 1920, 1 s.

17. Rozkaz Przewodniczący Wojenno-Rewolucyjnej Rady Respubliki, Komisarz ludowy do spraw wojennych L. Trockij. Zołnierze Polscy! W chwili - kiedy w tej wychwalanej przez burżuazje Najjaśniejszej Rzeczypospolitej Polskiej., b.m. 1920. Ulotka, 1 s.

18. Rozkaz. Doszło do wiadomości Politycznego Wydziału N-tej Armji, że ciemne indywidua... Ulotka, Równo 1920, 1 s.

19. Towarzysze Legjoniści. Dziś dzień 1-ego Maja, dzień solidarności robotniczej, dzień łączności całego proletarjatu międzynarodowego. Ulotka, b. m. 1920, 1 s.

20. Trzecia Międzynarodówka (Międzynarodowe stowarzyszenie robotników). Co to jest Międzynarodówka? Ulotka, b.m. 1920, 1 s.

21. Warszawska Rada delegatów żołnierskich. Żołnierze w odpowiedzi Piłsudskiemu! Naczelnika i Wodza Kapitalistycznej Polski! Ulotka, Warszawa 1920, 1 s.

22. Żołnierze Polscy chłopi i robotnicy! Dla jaśniepanów polskich wybiła ostatnia godzina... Ulotka, b.m. 1920, 1 s.

23. Żołnierze! Bracia! Towarzysze! Płatni pismacy, wysługujący się za judaszowe srebrniki kapitalistom i bankierom... Ulotka, Pociąg drukarnia Polit. Wydziału N-skiej Armji 1920, 1 s.

24. Żołnierze, robotnicy i włoścjanie Polski! Towarzysze! Rząd Polski rozpoczął wojne przeciw sowieckim republicom Rosji i Ukrainy. Ulotka, b.m. 1920, 2 s.

25. Zołnierzu i robotniku polski! Od ciebie zależy zaprzestanie dalszej bratobójczej walki! Ulotka, b.m. $1920,1 \mathrm{~s}$.

26. А. Руккас, Разом з польським військом. Армія Української Народної Республіки 1920 р. (структура, організація, чисельність та уніформа), Ніжин 2013, 464 с.

27. В. Сташис, Всеукраїнська надзвичайна комісія по боротьбі 3 контрреволюцією, спекуляцією, саботажем та службовими злочинами [w:] М. Бажан (голова редкол.), Українська радянська енциклопедія, Київ 1978, т. 2, с. 418.

28. Відозва до українського народу Комітету боротьби з більшовизмом. Листівка, [w:] [w:] О. Надтока (упоряд.), Українська революція 1917 - 1921 років у волянсіях: зб. документів, Київ 2018, с. 177.

29. Громадяне Української Народної Республіки! Листівка, [w:] О. Надтока (упоряд.), Українська революція 1917 - 1921 років у волянсіях: зб. документів, Київ 2018, с. 184.

30. Директорія, Рада Народних Міністрів УНР, 1918-1920: Документи і матеріали, 3 ч.: у 2 т.; відп. ред. і кер. упоряд. В. Верстюк, Київ 2006, т. 1, 687 с., т. 2, 744 с. 
31. Директорія, Рада Народних Міністрів УНР, 1918-1920: Документи і матеріали, 3 ч.: у 2 т.; відп. ред. і кер. упоряд. В. Верстюк, Київ 2006, т. 2, 744 с.

32. М. Омелянович-Павленко, Спогади командарма (1917-1920); упоряд. М. Ковальчук, Київ 2007, 608 с.

33. С. Литвин, Петлюра і Пілсудський: спільний похід на Київ 1920 року, http://www.reibert.info/threads/petlura-i-pilsudskij-pohid-na-kijiv-1920-roku.213217.html, 16.12.2011.

34. С. Петлюра, Статті. Листи. Документи; упоряд. В. Сергійчук, Київ 1999, т. 3, 614 с.

35. С. Петлюра, Статті. Листи. Документи; упоряд. В. Сергійчук, Київ 2006, т. 4, 706 с.

36. С. Литвин, Симон Петлюра у 1917-1926 роках. Історіографія та джерела: Монографія, Київ 2000, 464 с. С. Литвин, Суд історії: Симон Петлюра і петлюріана, Київ 2001, 640 с.

37. Спогади випускника Військового інституту іноземних мов (ВIIM) Міністерства оборони СРСР, командира 109 загону спецпропаганди 66-ї мотострілецької бригади Обмеженого контингенту радянських військ в Афганістані (ОКРВА) Сергія Небренчина «Оружие смыслов и нервов», http://www.clubvi.ru/news/2015/08/04.html, 04.08.2015.

38. Українська революція 1917 - 1921 років у волянсіях: зб. документів; уклав О. Надтока, Київ 2018, 281 с. та інші. 